\title{
LEAN THINKING IN A UK UNIVERSITY LAW CLINIC: A REFLECTIVE CASE
}

\section{STUDY}

Alex Nicholson E Dr. Alireza Pakgohar, Sheffield Hallam University ${ }^{1}$.

\section{Abstract}

A law clinic typically involves staff and students in a range of complex processes that are highly resource-intensive and which have the potential to detract from core value-adding activities. This paper aims to highlight the challenges associated with resourcing a university law clinic, and evaluate the extent to which lean management is able to provide solutions. It is submitted that proactive and deliberate application of lean management philosophies to law clinic process design has the potential to both reduce resource intensity and enhance value. A literature review was conducted in order to identify lean management principles and methodologies that might be applicable. A case study approach was then used to evaluate key resourcing challenges faced by a UK university law clinic and to explore the extent to which lean thinking might help to overcome them. There is very little literature which discusses the application of lean thinking in the higher education sector, and none which considers the university law clinic context

\footnotetext{
${ }^{1}$ Alex Nicholson is a Principal Lecturer and Deputy Head of Law at Sheffield Hallam University. Dr Alireza Pakgohar is a Senior Lecturer In Business Operations And Systems at Sheffield Hallam University.
} 
specifically. This paper will provide law school leaders with a resource that will enable them to evaluate and design their clinic processes more effectively, improving the wellbeing of clinic staff and enhancing the pedagogical value of clinic work for students. It will also contribute to the emerging body of literature which highlights the benefits of lean thinking within the higher education sector.

\section{INTRODUCTION}

\section{About the Law Clinic at Sheffield Hallam University}

The law clinic at Sheffield Hallam University (the 'Clinic') exists within the Helena Kennedy Centre for International Justice (HKC) and is underpinned by the HKC values, which include: access to justice; human rights; ethical practice; and equality ${ }^{2}$. It is regulated by the Solicitors Regulation Authority (which ultimately ensures the quality of the Clinic's advice and associated procedures) and operates on a purely pro bono basis, offering legal advice to staff, students and members of the public, across a range of areas of law.

Case work in the Clinic is conducted by undergraduate law students, under the supervision of academic staff who are typically also qualified solicitors. This work includes: interviewing clients; conducting legal research; drafting letters; and operating case management software. For client confidentiality reasons, the Clinic

\footnotetext{
${ }^{2}$ Helena Kennedy Centre. Helena Kennedy Centre for International Justice. (2019). Retrievd from: https://www.shu.ac.uk/about-us/academic-departments/law-and-criminology/the-helena-kennedycentre-for-international-justice.
} 
operates within a locked-down space comprising: a reception area; five meeting/teaching rooms; and an open-plan area in which students can complete case work.

The Clinic is currently an optional, 20 credit module for final year undergraduate law students at the university; there are 40 places in each academic year, which are offered on a first-come, first-served basis. Students are organised into 'firms' of six students and assigned a 'firm supervisor', who is both an academic member of staff and an experienced practitioner; many of the firm supervisors are qualified solicitors and retain their practising certificate. The supervisor's responsibility is to lead their firm(s) in taking on and acting for a number of clients over the course of the academic year, whilst at the same time ensuring that the pedagogical value of its activities for the students is maximised throughout. In recent years the Clinic has operated across a wide range of discipline areas, including: wills, family, small claims, company and property. Students gain academic credit for their work by compiling and submitting an individual portfolio, which is formally graded at the end of the academic year.

\section{Background}

The Law subject group at Sheffield Hallam University ('Subject Group') has a strong reputation for the applied nature of its courses, and in that sense is highly 
aligned to its wider organisational strategy ${ }^{3}$. However, the applied curriculum is becoming a highly competitive space within the market. Whilst the Subject Group was one of the first in the UK to offer its students the opportunity to take part in a law clinic - some 25 years ago - today most university law schools now offer some form of clinic or pro bono experience; what was once an "augmented deliverable" for the Subject Group is now an "expected deliverable" within the sector ${ }^{4}$. Therefore, in order to maintain its competitive advantage, the Subject Group has recently established its own fully functioning legal practice, SHU Law Limited ('SHU Law') (a move only made possible in recent years as a result of deregulation within the legal services sector under the Legal Services Act 2007, making it possible for nonlawyers and their organisations to own and manage a legal practice known as an "alternative business structure" or "ABS"), in order to facilitate a significant upscaling of its clinical provision both in terms of student numbers and the time spent by those students within a live-client environment.

The rationale for moving from a university law clinic to an ABS teaching law firm is two-fold. Firstly, this will expand the range of legal activities that can be undertaken, and secondly it will expand the number of students who can participate in clinical activities as part of their studies. It is the second of these two objectives that is the

\footnotetext{
3 Sheffield Hallam University. Transforming Lives. (2017). Retrieved from: https://www.shu.ac.uk/ /media/home/campaigns/files/transforming-lives.pdf.

${ }^{4}$ Levitt, T. 'Marketing Success Through Differentiation-of Anything'. (1980). Harvard Business Review, 58(1), 83-91
} 
focus of this paper. The intention is to move from 40 students undertaking 20 credits of clinical study in their final year, to all students undertaking clinical study, across all three years of their programme. Once fully operational, approximately 750-900 law students will be studying within SHU Law at any one time, many of whom will be spending up to three times more of their time engaged in clinical activities than has historically been the case.

The move to SHU Law therefore represents a vast upscaling of the current clinical provision offered by the Clinic. However - as is common within the sector ${ }^{5}$ the learning and teaching process that operates in the Clinic is resource intensive, and this presents certain challenges that risk being compounded by the planned upscaling.

Given the increasing focus on employability within the higher education ('HE') sector (as evidenced by its key role in the assessment of teaching quality in the UK; see Office for Students, 2018), the value of clinical legal education as a means of preparing students for employment ${ }^{6}$, and the potential for such activities to count as qualifying work experience under the new framework for qualification as a solicitor

\footnotetext{
${ }^{5}$ Bilgin, A. A., Rowe, A. D., \& Clark, L. 'Academic workload implications of assessing student learning in work-integrated learning'. (2017). Asia-Pacific Journal of Cooperative Education, 18(2), 167-183. ${ }^{6}$ Bleadsdale-Hill, L., \& Wragg, P. 'Models of Clinic and Their Value to Students, Universities and the Community in the post-2012 Fees Era'. (2013). International Journal of Clinical Legal Education, 19, 257270 .
} 
in England and Wales ${ }^{7}$, it seems likely that many other law schools will also seek to expand their clinical activities in the coming months and years. Using the Clinic as a case study, this paper explores the extent to which lean management principles and methodologies are able to support the development of new and/or revised processes that might assist law clinics - both in the UK and internationally - to enhance their effectiveness, efficiency, scalability, and long-term sustainability.

The paper is organised in six parts. The next section reviews the lean management literature in general and that which relates to $\mathrm{HE}$ in particular. Research methodology is discussed in Section 3. A case study analysis of existing Clinic practices and discussion of findings with resultant proposals and recommendations for law clinic process design are then outlined in Section 4. The main conclusions are then presented in Section 5, together with a summary of limitations and suggestions for future research.

\section{LEAN MANAGEMENT IN THEORY: A VIEW FROM THE LITERATURE}

Within operations and process management, 'lean' is a multifaceted and evolving concept, encompassing a collection of related ideas and methodologies, and a range of almost synonymous terms. Its origins can be found in the Toyota Production System which rose to international fame in the mid-twentieth century for its high

\footnotetext{
${ }^{7}$ Dunn R., Roper V., \& Kennedy, V. ‘Clinical legal education as qualifying work experience for solicitors'. (2018). The Law Teacher, 52(4), 439-452.
} 
quality and efficient approach to automobile manufacturing and logistics ${ }^{8}$, and then in the seminal work of Krafcik who coined the phrase "lean production"9 to describe manufacturing processes and systems that were designed to eliminate wastes (or "muda") and maximise both quality and continuous flow. Krafcik found that such lean management policies had significant potential to enhance both productivity and quality. Initially 'lean' was considered to be a purely manufacturing concept, but today it is accepted that lean principles have broader application to operations more generally ${ }^{10}$.

Lean production can be divided into five distinct phases that have the potential to assist organisations across the world in all industries to improve their processes and to eliminate their wastes: (1) identify precisely what customers value; (2) establish precisely how that value is delivered by the organisation, and eliminate activities that do not add value; (3) ensure that products and/or information flow(s) seamlessly through the value process; (4) deliver only what is demanded by the customer; and (5) strive for perfection in process design ${ }^{11}$. Within each of these phases, a myriad of scientific tools and techniques exist that can be utilised to

\footnotetext{
8 see Ohno, T. Toyota Production System: Beyond Large-Scale Production, (1988). Cambridge, USA: Productivity Press. (Original work published 1978).

${ }^{9}$ Krafcik, J. F. 'Triumph of the Lean Production System. Sloan Management'. (1988). Review, 30(1), 4152.

${ }^{10}$ Slack, N., Brandon-Jones, A., Johnston, R., \& Betts, A. Operations and Process Management (2015). (4th ed). Harlow: Pearson., pp. 364

${ }^{11}$ Womack, J. P., \& Jones, D. T. Lean Thinking. (2003). (2nd ed). London: Simon \& Schuster.
} 
analyse existing processes, identify muda, and devise process improvement solutions.

The application of lean thinking in manufacturing has been extensively studied ${ }^{12}$.

The application of lean principles in the service sector has also been studied for several years ${ }^{13}$. In their study, Piercy \& Rich ${ }^{14}$ argued that a lean approach can be relatively easy to apply with a minimal investment in training, producing significant improvement across an organisation's activities.

${ }^{12}$ Forza, C. 'Work Organization in Lean Production and Traditional Plants: What Are the Differences?'. (1996). International Journal of Operations \& Production Management, 16(2), 42-62.; Motwani, J. 'A Business Process Change Framework for Examining Lean Manufacturing: A Case Study'. (2003). Industrial Management \& Data Systems, 103(5), 339-346.; Kumar, M., Antony, J. Singh, R. K., Tiwari, M. K., \& Perry, D. 'Implementing the Lean Sigma framework in an Indian SME: a case study'. (2006). Production Planning and Control, 17(4), 407-423.; Pattanaik, L.N., \& Sharma, B.P. 'Implementing lean manufacturing with cellular layout: a case study'. (2009). International Journal of Advanced Manufacturing Technology, 42(7), 772-779.; Vinodh, S., Gautham, S.G. \& Anesh Ramiya R. 'Implementing lean sigma framework in an Indian automotive valves manufacturing organisation: a case study'. (2011). Production Planning \& Control, 22(7), 708-722.; Forno, A., Pereira, F., \& Forcellini, F. 'Value Stream Mapping: a study about the problems and challenges found in the literature from the past 15 years about application of Lean tools'. (2014). The International Journal of Advanced Manufacturing Technology, 72(5-8), 779-790.; Bevilacqua, M., Ciarapica, F. E. \& Paciarotti, C. 'Implementing lean information management: the case study of an automotive company'. (2015). Production Planning \& Control, 26(10), 753-768.; Johansson, P. E., \& Osterman, C. 'Conceptions and operational use of value and waste in lean manufacturing - an interpretivist approach'. (2017). International Journal of Production Research, 55(23), 6903-6915.; Dadashnejad, A., \& Valmohammadi, C. 'Investigating the effect of value stream mapping on overall equipment effectiveness: a case study'. (2019). Total Quality Management \& Business Excellence, 30(3-4), 466-482.

${ }^{13}$ Womack, J. P., \& Jones, D. T. Lean Thinking (2003). (2nd ed). London: Simon \& Schuster.; Atkinson, P. 'Creating and implementing lean strategies'. (2004). Management Services, 48(2), 18-33.; Abdi, F., Shavarini, S. \& Hoseini, S. 'Glean lean: how to use lean approach in services industries?' (2006). Journal of Services Research, 6, 191-206.; Piercy, N., \& Rich, N. Lean transformation in the pure service environment: the case of the call service centre. (2009). International Journal of Operations \& Production Management, 29(1), 54 - 76.; Leyer, M., Vogel, L., \& Moormann, J., 'Twenty years research on lean management in services: results from a meta-review'. (2015). International Journal of Services and Operations Management, 21(4), 389-419.

${ }^{14}$ Piercy and Rich, (2009). 
As lean thinking in practice has moved beyond the manufacturing context, so too has the literature. However, there are still many industries/sectors in relation to which the applicability and benefits of lean thinking remain under-researched, and recent comprehensive and influential literature reviews call for the implementation of lean thinking in a wider range of fields ${ }^{15}$.

In response to these calls, very recent studies have begun to evaluate the utility of lean thinking within public sector ${ }^{16}$ and even education contexts ${ }^{17}$, but its explicit application within HE has thus far been relatively limited ${ }^{18}$. Some research has emerged which specifically evidences the benefits of lean thinking for the sector, although it typically relates to central university functions ${ }^{19}$ rather than curriculum

\footnotetext{
${ }^{15}$ Marodin, G. A., \& Saurin, T. A. 'Implementing lean production systems: research areas and opportunities for future studies'. (2013). International Journal of Production Research, 51(22), 6663-6680;; Jasti, N. V. K., \& Kodali, R. 'Lean production: literature review and trends'. (2015). International Journal of Production Research, 53(3), 867-885.

${ }^{16}$ Kregel, I., \& Coners, A. 'Introducing Lean Six Sigma to a German municipality: an action research report'. (2018). International Journal of Lean Six Sigma, 9(2), 221-237.

${ }^{17}$ Sfakianaki, E., \& Kakouris, A. 'Lean thinking for education: development and validation of an instrument'. (2019). International Journal of Quality \& Reliability Management.

${ }^{18}$ Hess, J.D., \& Benjamin, B. A. 'Applying Lean Six Sigma within the university: opportunities for process improvement and cultural change.' (2015). International Journal of Lean Six Sigma, 6(3), 249262.;

Thomas, A., Antony, J., Francis, M., \& Fisher, R. 'A comparative study of Lean implementation in higher and further education institutions in the UK'. (2015). International Journal of Quality \& Reliability Management, 32(9), 982-996.; Narayanamurthy, G., Gurumurthy, A., and Chockalingam, R. 'Applying lean thinking in an educational institute - an action research'. (2017). International Journal of Productivity and Performance Management, 66(5), 598-629.

${ }^{19}$ see for example: Balzer, W. K., Brodke, M. H., \& Kizhakethalackal, E. T. ‘Lean higher education: successes, challenges, and realizing potential'. (2015). International Journal of Quality \& Reliability Management, 32(9), 924-933.
} 
design. Particularly at a time when the value of university education is being closely scrutinised ${ }^{20}$ there is both scope for and need of greater utilisation of lean management methodologies within faculties and at a course level ${ }^{21}$.

In HE and university settings, lean principles could be utilised to improve processes in: curriculum delivery; business and auxiliary services; admissions and enrolment management; and research ${ }^{22}$. However, some caution here is appropriate. Whilst the potential benefits of lean management are well established, its application to complex services may attract opposition from professionals who object to apparent attempts to break down their work into simplified and measurable, discrete processes $^{23}$. This argument is particularly likely to arise within a HE context as many academics may view 'efficiency' as a commercial aim that directly threatens the educational aims of the university - care must be taken to ensure that employees involved in any lean management intervention understand how any changes will result in enhancements rather than compromising the value delivered to students.

\footnotetext{
${ }^{20}$ Department for Education. Review of Post-18 Education and Funding: Terms of Reference. (2018). Retrieved from: https://assets.publishing.service.gov.uk/government/uploads/system/uploads/attachment_data/file/68 2348/Post_18_review_-_ToR.pdf.; Nicholson, A. 'The value of a law degree.' (2019). The Law Teacher, DOI: 10.1080/03069400.2019.1633117.9

${ }^{21}$ Emiliani, M. L. ‘Engaging faculty in Lean teaching'. (2015). International Journal of Lean Six Sigma, 6(1).

${ }^{22}$ Hess, J.D., \& Benjamin, B. A. 'Applying Lean Six Sigma within the university: opportunities for process improvement and cultural change'. (2015). International Journal of Lean Six Sigma, 6(3), 249-262 ${ }^{23}$ Slack, N., Brandon-Jones, A., Johnston, R., \& Betts, A. Operations and Process Management (2015). (4 $4^{\text {th }}$ ed). Harlow: Pearson, pp. 26
} 
There are some articles about the successful application of lean thinking in HE: Emiliani ${ }^{24}$ deployed a popular continuous improvement methodology to enhance the processes for ten courses contained in a part-time executive master's degree program in management; Stratton, Rudy, Sauer, Perman and Jennings ${ }^{25}$ used lean thinking philosophies to improve medical education processes; and Doman ${ }^{26}$ utilised lean management tools to improve university grade change processes, involving students in the process.

Thomas et al. ${ }^{27}$ conducted an investigation in the UK into the differences that exist between HE Institutions ('HEI') and Further Education Institutions ('FEI') in the methods and practices deployed in their development and implementation of lean initiatives. The research revealed that UK FEIs have used lean principles over a longer period and gained more experience of its applications than their $\mathrm{HE}$ counterparts, though typically this has been achieved through consultancy-based projects, rather than by being embedded into organisational culture. By contrast, lean initiatives in UK HEIs have been conducted in a more systematic and holistic

\footnotetext{
${ }^{24}$ Emiliani, M.L. 'Using "kaizen" to improve graduate business school degree programs'. (2005). Quality Assurance in Education, 13(1), 37-52.

${ }^{25}$ Stratton, T.D., Rudy, D.W., Sauer, M.J., Perman, J.A., \& Jennings, C.D. 'Lessons from industry: one school's transformation toward 'lean' curricular governance'. (2007). Academic Medicine, 82(4), 331-340. ${ }^{26}$ Doman, M.S. 'A new lean paradigm in higher education: a case study'. (2011). Quality Assurance in Education, 19(3), 248-262.

${ }^{27}$ Thomas, A., Antony, J., Francis, M., \& Fisher, R. 'A comparative study of Lean implementation in higher and further education institutions in the UK'. (2015). International Journal of Quality \& Reliability Management, 32(9), 982-996.
} 
manner across the organisations, albeit these are mostly still in the early stages of implementation.

Narayanamurthy et al. ${ }^{28}$ proposed a structured procedure for the implementation of lean thinking in an educational institute in India. They compared performance measures such as absenteeism, utilisation, and learning before and after implementation of lean solutions to prove the effectiveness thereof.

The application of lean thinking in legal practice is a neglected area in academic journal papers. To the best of the authors' knowledge, Henderson ${ }^{29}$ is the only published paper that looks at the lean law concept as an alternative approach for larger law firms. However, this study did not address any specific application of lean thinking in a law firm as a case study. Moreover, the authors were not able to find a paper which considers the application of lean methodologies to a law clinic context. So this paper will contribute to lean management literature in the areas of legal practice and legal education.

\footnotetext{
${ }^{28}$ Narayanamurthy, G., Gurumurthy, A., and Chockalingam, R. Applying lean thinking in an educational institute - an action research. (2017). International Journal of Productivity and Performance Management, 66(5), 598-629.

${ }^{29}$ Henderson, W. 'From Big Law to Lean Law'. (2014). International Review of Law and Economics, 38, 516.
} 


\section{RESEARCH METHODOLOGY}

The aim of this study is to address the challenges associated with resourcing in a university law clinic, and to evaluate the extent to which lean management tools and techniques may be able to provide solutions. To achieve this, a case study approach was adopted to investigate the applicability of lean management tools to the Clinic's operational activities.

The utilised case study strategy in this paper is in line with many other research papers in lean management studies ${ }^{30}$. A good case study reveals how a problem can be dealt with ${ }^{31}$.

The lead researcher is an academic from within the Subject Group, with first-hand experience of and leadership responsibility for the Clinic's processes. This role is important both to facilitate data collection, but also since leadership commitment is a key factor of success in any lean management initiatives ${ }^{32}$. The second researcher is

\footnotetext{
30 Seth, D., \& Gupta, V. 'Application of value stream mapping for lean operations and cycle time reduction: an Indian case study'. (2005). Production, Planning \& Control, 16(1), 44-59.; Doman, M.S. 'A new lean paradigm in higher education: a case study'. (2011). Quality Assurance in Education, 19(3), 248-262.; Bevilacqua, M., Ciarapica, F. E. \& Paciarotti, C. 'Implementing lean information management: the case study of an automotive company'. (2015). Production Planning \& Control, 26(10), 753-768.; Narayanamurthy, G., Gurumurthy, A., and Chockalingam, R. 'Applying lean thinking in an educational institute - an action research'. (2017). International Journal of Productivity and Performance Management, 66(5), 598-629.

${ }^{31}$ Childe, S. 'Case studies in the management of operations'. (2017). Production Planning $\&$ Control, 28(1), 1-1.

${ }^{32}$ Alefari, M., Salonitis, k., \& Xu, Y. 'The role of leadership in implementing lean manufacturing'. (2017). Procedia CIRP, 63, 756-761.
} 
an academic from outside of the Subject Group, but with particular expertise in lean management; this researcher is able to bring a degree of objectivity to the study.

The roles and responsibilities of the research team enabled a participative approach to tackling the objectives of the study. Various lean tools have been deployed to understand their applicability to the current clinic context.

The researchers had access to all relevant documentation such as university procedures and regulations, minutes of meetings and other related $\operatorname{archives}^{33}$. Data were also collected through personal observations and communication with current Clinic staff.

\section{CASE STUDY ANALYSIS}

\section{IV.I USING LEAN TOOLS TO IDENTIFY CURRENT ISSUES WITH CLINIC}

\section{PROCESS}

\section{Pareto Analysis}

Key to the success of any lean management intervention is an assessment of the current state, followed by effective communication of the impetus for change to relevant parts of the organisation ${ }^{34}$. To achieve this, diagnostic tools can be useful

\footnotetext{
${ }^{33}$ Yin, R.K. Case study research and applications: Design and Methods. (2018). Los Angeles: SAGE.

${ }^{34}$ Feld, W. M. Lean Manufacturing: Tools, Techniques and How to Use Them. (2001). Boca Raton: CRC Press., pp.7
} 
not only in identifying what the current issues are, but also in illustrating/explaining those issues to colleagues/employees ${ }^{35}$.

The reported experience of teaching staff within the Clinic was that they spent vastly more working hours supervising students in this context, than the university is able to award them as part of its academic work planning process. The authors therefore initially conducted a Pareto analysis with Clinic staff (see Figure 1) in order to ascertain where academic time was predominantly being spent. A Pareto analysis plots time engaged against process activities in a graphical form, with the aim of identifying which of those activities dominate. A common finding is that a majority (often as much as $80 \%$ ) of process time is spent on a minority (often as little as $20 \%$ ) of process activity; a phenomenon commonly referred to as the "Pareto Principle" 36. Such an analysis provides a useful focus for process improvement.

As the Pareto analysis at Figure 1 illustrates: academics working in the Clinic report that, as much as $50 \%$ of their total time spent working in the Clinic or on Clinic related activities is being spent on marking formative work produced by students on an almost daily basis, and providing feedback on that work.

\footnotetext{
${ }^{35}$ see Slack, N., Brandon-Jones, A., Johnston, R., \& Betts, A. Operations and Process Management (2015). (4th ed). Harlow: Pearson., pp. 459-463

${ }^{36}$ Doyle, C. 'Pareto Principle.' In A Dictionary of Marketing (2016). (4 $4^{\text {th }}$ ed.). Oxford: Oxford University Press.
} 


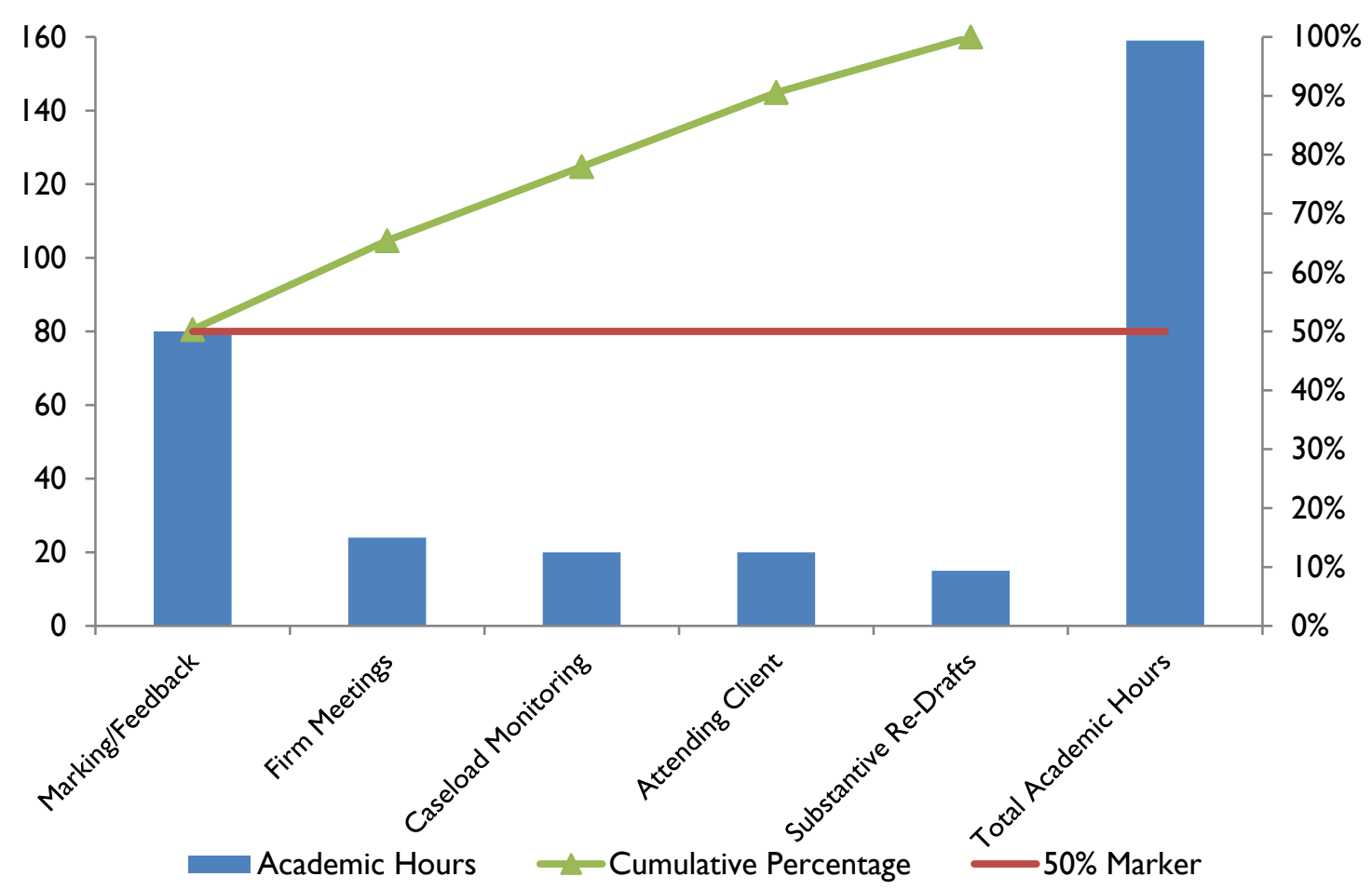

Fig. 1: Pareto Analysis of Clinic Supervisor Workload

\section{Cause and Effect Analysis}

Next, the authors mapped out the cited reasons for work overloading into an Ishikawa (or "fishbone") diagram, which serves to highlight possible cause and effect relationships that might be worthy of further investigation and/or process improvement initiatives. The resultant diagram at Figure 2 illustrates some of the reasons why members of Clinic staff believed that they were overloaded. It is evident from these wide ranging factors that there are a range of inherent and systemic issues with the Clinic process design which would benefit from a thorough examination. 


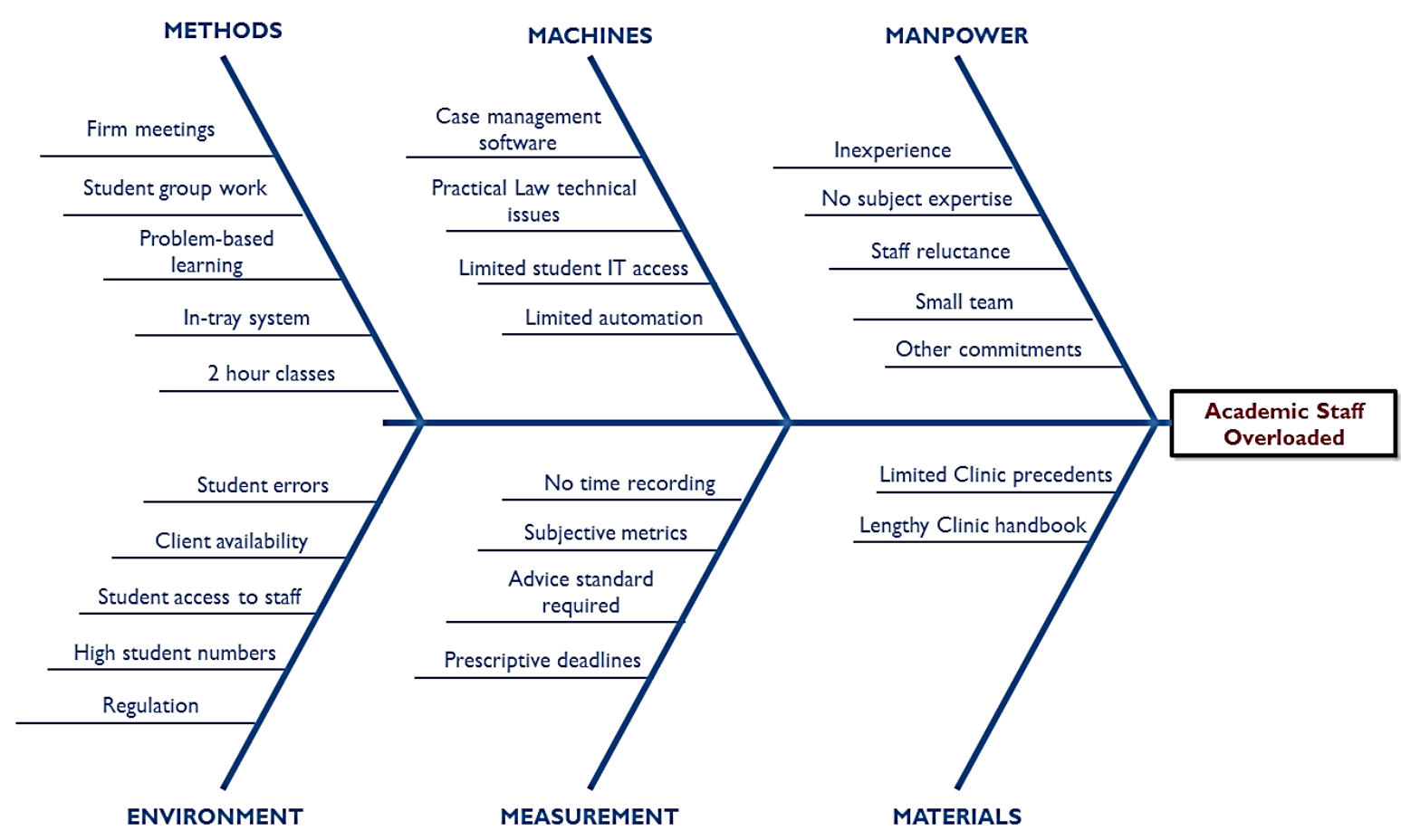

Fig. 2: Cause and effect analysis

It is important to remember that the focus of any such review must not be on efficiency alone, as this risks merely redesigning and improving outdated processes that may no longer be fit for purpose, and potentially missing opportunities to completely reengineer the way that value is delivered, which might both reduce cost and increase quality ${ }^{37}$. Certain historic assumptions within the Subject Group currently underpin the way that processes are designed and evaluated, for example: members of staff are either clinical or academic; clinical members of staff have practice experience and/or practising certificates; 'clinical' modules involve regular marking and feedback whilst 'academic' modules do not; and firm supervisors must

\footnotetext{
${ }^{37}$ Hammer, M. ‘Reengineering work: don't automate, obliterate'. (1990). Harvard Business Review, 68(4), 103-112.
} 
ensure the accuracy and quality of client advice. If the Subject Group is to maintain its competitive edge in the face of vastly changing market demands, and to deliver on its commitment to offer all students, at all levels, employability-enhancing work experience in SHU Law, it is essential that assumptions such as these are not allowed to dictate the limits of what is possible.

\section{Value Stream Mapping ('VSM')}

Some lean management techniques serve both a diagnostic and future planning function - value stream mapping is one such technique, which can be used to illustrate both the current and future states of a value process ${ }^{38}$. Womack and Jones ${ }^{39}$ argue that value stream mapping enables managers to distinguish between those activities which create value (or which are simply unavoidable), from muda: those which are wasteful and avoidable. In a service context, examples of muda might include: excessive quality, delay, under-utilised resources, duplication and/or a lack of standardisation ${ }^{40}$.

\footnotetext{
${ }^{38}$ Forno, A., Pereira, F., \& Forcellini, F. 'Value Stream Mapping: a study about the problems and challenges found in the literature from the past 15 years about application of Lean tools'. (2014). The International Journal of Advanced Manufacturing Technology, 72(5-8), 779-790.

${ }^{39}$ Womack, J. P., \& Jones, D. T. Lean Thinking (2003). (2nd ed). London: Simon \& Schuster., pp.20

${ }^{40}$ Andrés-López, E., González-Requena, I., \& Sanz-Lobera, A. 'Lean Service: Reassessment of Lean Manufacturing for Service Activities'. (2015). Procedia Engineering, 132, 23-30
} 
Figure 3 shows a value stream map of the current learning and teaching process in the Clinic; it highlights the flow of information between process participants at each stage of the Clinic process

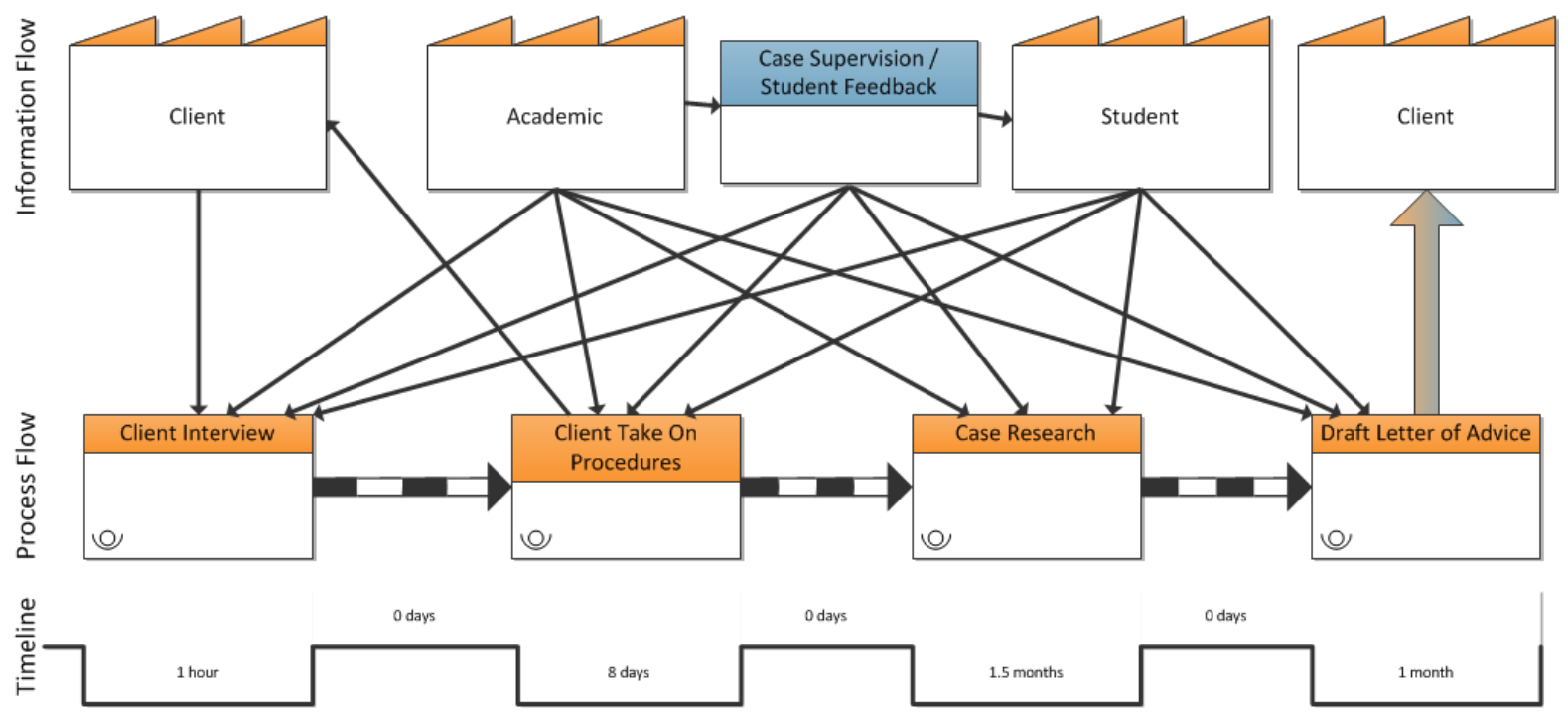

Fig. 3: Current VSM

This value stream map illustrates that the current process comprises a highly complex, multipartite and continuous exchange of information between academics and students. Not only is the academic supervisor themselves directly involved at all stages of the Clinic process, but so too is each and every student, albeit to a greater or lesser extent from time to time. Most significantly, at each and every step in the process the supervisor strives to simultaneously fulfil a dual function, ensuring both that: (1) (in their capacity as a practitioner) the particular step is successfully completed for the benefit of the client; and (2) (in their capacity as an educator) the full pedagogical value of completing that step is delivered for the benefit of each 
student involved in that task. Once this is scaled up to reflect a particular supervisor's responsibility for multiple clients and any significant numbers of students - recognising also that individual cases each have their own unique features and timelines - the challenge is clear: current Clinic process design necessitates significant and inherent duplication of client work, accompanied by substantial bespoke student feedback. Although many of these interactions are necessary - and others do of themselves create value for students - others may represent avoidable waste.

$\mathrm{Ohno}^{41}$ famously identified seven different categories of waste. Whilst these are difficult to translate into a professional services context, subsequent literature has also referred to 'service wastes' and 'new wastes', and these have included: "excessive information and communication"; "waste of knowledge"; "waste of time"; and "duplication" ${ }^{42}$, and examples of these can be seen in the present context.

For example, the current process results in a very lengthy cycle time - meaning that clients have to wait up to three months for advice; this in turn restricts both the quality and quantity of the legal work that the Clinic can attract, impacting upon value for the students. Similarly, the complexity of the working environment means

${ }^{41}$ Ohno, T. Toyota Production System: Beyond Large-Scale Production, (1988). Cambridge, USA: Productivity Press. (Original work published 1978).

${ }^{42}$ Bicheno, J., \& Holweg, M. The Lean Toolbox: The Essential Guide to Lean Transformation (2009). (4th ed.) Buckingham: PICSIE Books., pp. 25-26 
that students necessarily spend a significant amount of time getting up to speed with these working processes, time that could arguably be spent on more pedagogically 'valuable' learning activities ${ }^{43}$.

\section{IV.II PROPOSALS AND RECOMMENDATIONS FOR LAW CLINIC PROCESS}

\section{DESIGN}

\section{Towards a New Value Stream Map}

As noted above, the prevailing challenge with the current Clinic process appears to be the volume, variety and frequency of information exchange between clients, academics and students in relation to case work and student feedback. Essentially, the same individuals are involved in the vast majority of the processes, and there is significant duplication; both academics and students work on almost every aspect of a client's case. This raises the question whether, by separating out the processes involved, it might be possible to enhance the value of those processes. Figure 4 illustrates just one way in which this might be achieved. In this example, specific solicitors are tasked to take responsibility for managing the cases, and simply delegate discrete tasks for students to complete, with the support of a wider group of academics. This approach has the advantage of preserving the quality of student feedback (and thus pedagogical value) that can be provided through the Clinic,

\footnotetext{
${ }^{43}$ Nicholson, A. 'Research-informed teaching: a clinical approach'. (2017). The Law Teacher, 51(1), 4055., pp. 50
} 
whilst at the same time limiting substantially the range and scope of activities that any single member of staff or student is responsible for at any one time.

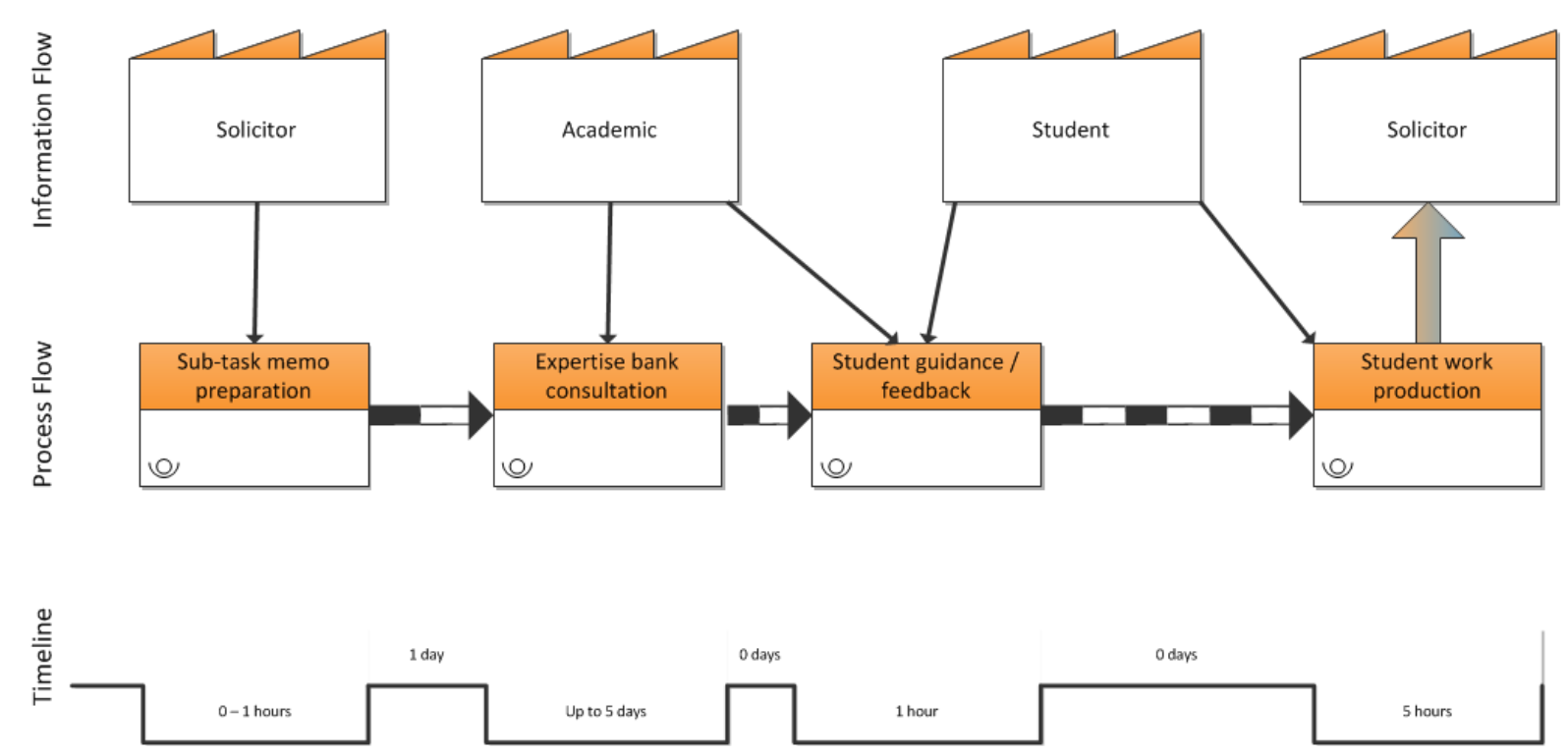

Fig. 4: Future VSM

Whilst this map may itself represent a slight oversimplification (since academics may in reality look at student work more than once during different stages of its production) the vastly reduced complexity of the process is nevertheless very evident. The value stream mapping process makes it possible to evaluate at a glance the complexity, speed and value of the process and here each of those elements are vastly improved in the new approach. Clients stand to benefit from faster turnaround times and student time would be spent exclusively on activities designed to maximise the educational value of their Clinic experience. Whilst there is undoubtedly some pedagogical value in students learning how to comply with 
office procedure, the new approach ensures that this does not become the focus of the experience, particularly given that office processes and procedures will vary significantly between legal practices.

As noted above, under the current structure (see Section 4) academics working within the Clinic fulfil a dual function in that they each take responsibility for delivery of their cases for the benefit of their clients (in their capacity as practitioners) whilst simultaneously working to ensure that maximum pedagogical value is delivered at every stage for the benefit of their students. The key differences between the current and future VSMs are: (1) a degree of separation between solicitors running the cases (who would take on only such cases as fall squarely within their own expertise) and academics supervising students; and (2) the creation of an 'expertise bank': a pool of academic and/or practitioner 'experts' that the academic supervisor can draw on for advice (and thereby expedite any research/professional updating that might be required in order to support students to complete a particular task), either in relation to the relevant law or in relation to more practice-based skills such as drafting.

This division of labour not only reduces duplication, but it enables each participant in the process (solicitor, academic and student) to focus almost exclusively on the aspects of Clinic process that are most useful/appropriate to their needs and expertise, thus potentially enhancing the overall value delivered through that 
process to client and student stakeholders, widening the group of academics who would be able to supervise students in the Clinic, and raising satisfaction amongst all stakeholder groups. In that sense it is also conceivable that these changes might benefit staff wellbeing, beyond merely the effect of a reduction in workload.

\section{Process Design}

The value stream mapping process naturally raises more detailed questions about process design. At a macro level, the current learning and teaching process is low volume, high variety, high variation, and high visibility, and these factors make it a high-cost ${ }^{44}$, 'professional service' process that can be difficult to evaluate and improve ${ }^{45}$. Whilst it is unlikely that this process could ever be sufficiently broken down to be credibly categorised as a more efficient 'service shop' process (for example such as those employed in restaurants, banks and other similar consumer contexts), the value stream mapping exercise clearly indicates that it should be possible to remove some activities from the core process. There are some clear risks of dividing up takes in this way - for example, it may create more monotonous tasks and reduce flexibility ${ }^{46}$. However, the present overloading and the need for expansion necessitate some action in this area, and these are risks that can be managed.

\footnotetext{
${ }^{44}$ Slack, N., Brandon-Jones, A., Johnston, R., \& Betts, A. Operations and Process Management (2015). (4 $4^{\text {th }}$ ed). Harlow: Pearson., pp. 24

${ }^{45} \mathrm{Ibid},(2015)$, pp. 124

${ }^{46}$ Ibid, (2015)., pp.135
} 
Taking account of the value stream mapping process and the further process design considerations outlined here, Figure 5 illustrates a possible learning and teaching process. This is presented in a swim lane diagram format, which has the advantage of showing how and when the different participants in the process engage with it.

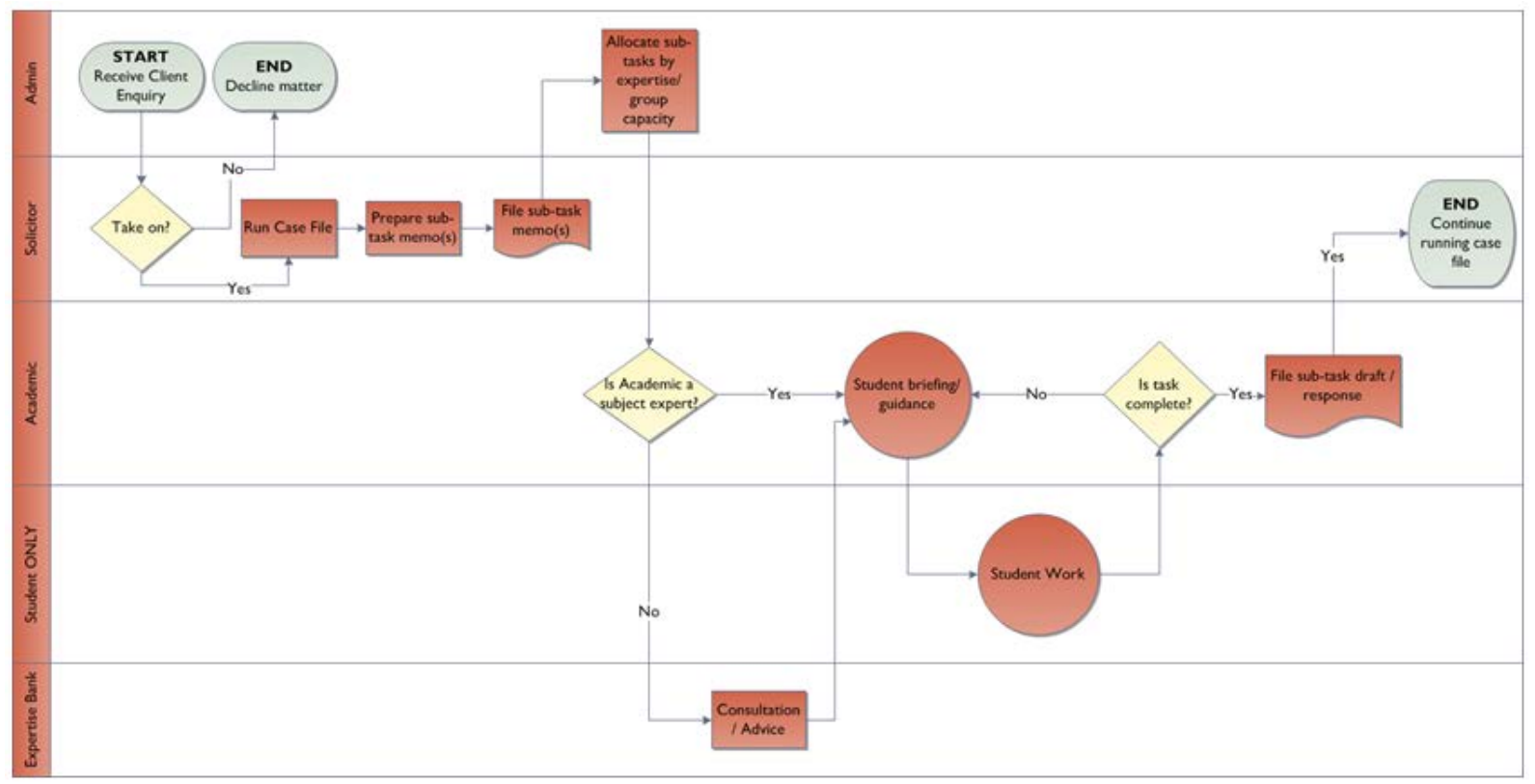

\section{Fig. 5: Proposed Process Map}

As can be seen from this process map, each process participant has a well-defined and tightly controlled remit, which enables them to focus exclusively on their own value-adding activity: solicitors are responsible for running the cases, meeting deadlines, and protecting the best interests of the client (ultimately signing off - and where necessary completing - all client work); academic supervisors are tasked with developing students' knowledge, understanding and skills in relation to clinical tasks; academics from within the 'Expertise Bank' are on hand to provide efficient, 
subject-specific guidance to academic supervisors as required from time to time; and students are given discrete delegated tasks (together with appropriate context) and high quality feedback, which facilitate maximum learning gain. Such a process would both resemble (in relation to the nature of and approach to delegation) and potentially improve upon (in relation to the quality of feedback) the learning and teaching process typically experienced by trainee solicitors in practice ${ }^{47}$.

\section{Continuous Improvement}

A strong feature of 'lean' is its association with the concept of 'continuous improvement' - as Bicheno and Holwegput it "mistakes are seen as 'opportunities to improve', not as something that needs to be monitored and punished" ${ }^{48}$. For that reason - if implemented - this new process should not be the end of the matter. To truly achieve lean practice within a law clinic context, there must also be processes of performance measurement and management; such processes enable an organisation to regularly identify where it is, confirm where it wants to be, and then communicate that trajectory to stakeholders, driving progress in the right direction ${ }^{49}$.

Particularly in a not-for-profit context such as a university, the most important measureable outcome has to be quality. Before seeking to measure quality, it is

\footnotetext{
${ }^{47}$ Nicholson, A. 'Research-informed teaching: a clinical approach'. (2017). The Law Teacher, 51(1), 40-55.

${ }^{48}$ Bicheno, J., \& Holweg, M. The Lean Toolbox: The Essential Guide to Lean Transformation (2009). (4 ${ }^{\text {th }}$ ed.)

Buckingham: PICSIE Books., pp.9

${ }^{49}$ Neely, A. D. Measuring Business Performance. (1998). London: Profile Books.
} 
essential to define what we mean - different conceptions of 'quality' within the organisation will pull its employees in different directions. The definition and accurate measurement of quality within service sectors is difficult, not least because of the highly subjective and arguably unreliable nature of common metrics such as customer (or in the present case: client and/or student) satisfaction. Gronroos (1988) acknowledges this challenge, and argues that it is the customers' definition of quality that counts; he proposes six criteria of good perceived service quality, four of which relate not to the technical aspects of the service being provided, but to the so-called 'functional quality dimension', i.e. the way in which an organisation's employees interact with customers whilst the service outcomes are being delivered ${ }^{50}$. Further support for this idea can be found in the work of Parasuraman, Zeithaml and Berry ${ }^{51}$, who identified 10 "determinants of service quality"; only three of these ("competence", "credibility" and "tangibles") relate to traditional 'technical' aspects of quality, whilst the remainder are concerned with the way in which the customer experiences the core elements of the service.

These findings suggest that, whilst 'technical' aspects - such as the reputation and knowledge of the academics teaching on a particular course - are important, the broader 'functional' aspects of quality heavily impact student satisfaction levels and

\footnotetext{
${ }^{50}$ Gronroos, C. 'Service Quality: The Six Criteria Of Good Perceived Service Quality'. (1988). Review of Business, 9(3), 10-13.

${ }^{51}$ Parasuraman, A., Zeithaml, V.A., \& Berry, L.L. 'A Conceptual Model of Service Quality and Its Implications for Future Research'. (1985). Journal of Marketing, 49(4), 41-50.
} 
therefore arguably perceptions of quality ${ }^{52}$. A lean approach therefore suggests that the focus of continuous improvement should be the quality of the student experience, which very much includes the quality of the learning and teaching process itself.

In measuring and managing customer orientation and value, a fundamental choice is which metrics to use. Kaplan and Norton famously claimed that "[w]hat you measure is what you get", and devised a 'balanced scorecard' which would enable businesses to measure performance from different perspectives ${ }^{53}$. Within the commercial context for their work, the 'balanced scorecard' was designed to measure performance beyond merely the financial (e.g. customer satisfaction, wider strategic objectives etc.), but this concept has utility within HE also. In an age of consumerism and significant emphasis on student satisfaction as a measure of teaching quality, there is a risk that courses are shaped solely to ensure satisfaction which risks undermining the true purposes of $\mathrm{HE}^{54}$. A 'balanced scorecard' approach may help the Clinic to ensure that it is achieving its strategic objectives and transforming students' lives; students may be 'satisfied' with their experience, but

\footnotetext{
${ }^{52}$ see for example: Smimou, K., \& Dahl, D. W. 'On the Relationship Between Students' Perceptions of Teaching Quality, Methods of Assessment, and Satisfaction'. (2012). Journal of Education for Business, 87(1), 22-35.

; and Xiao, J., \& Wilkins, S. 'The effects of lecturer commitment on student perceptions of teaching quality and student satisfaction in Chinese higher education'. (2015). Journal of Higher Education Policy and Management, 37(1), 98-110.

${ }^{53}$ Kaplan. R. S., \& Norton, D. P. ‘The Balanced Scorecard - Measures That Drive Performance'. (1992). Harvard Business Review, 70(1), 71-79.

${ }^{54}$ Naidoo, R., Shankar, A., \& Veer, E. 'The consumerist turn in higher education: Policy aspirations and outcomes'. (2011). Journal of Marketing Management, 27(11-12), 1142-1162.
} 
the real question is whether it has transformed their ability to lead fulfilling and prosperous lives that benefit both themselves and the wider societies that they inhabit.

Since quality is about customer value, a balanced scorecard approach may enable the Subject Group to better measure and manage performance improvement by ensuring that the focus remains on maximising consumer value - continuously - in all processes, and eliminating processes/steps which do not deliver that consumer value.

\section{CONCLUSIONS}

To the extent that lean management is seen merely as the use of scientific methods in solving business problems, its benefits are incontrovertible. The application of lean management principles and methodologies to existing Clinic processes has revealed potential opportunities to dramatically increase the Subject Group's clinical capacity whilst enhancing customer value. The proposed new learning and teaching process above eliminates and/or simplifies those activities that constitute 'waste', maximising the resources available for high value learning activities. The results may prove useful not only to other law clinic operators, but to the entire HE sector more widely as they demonstrate the applicability and usefulness of lean thinking in that context. 
However, this definition and its focus on 'methods' is potentially misleading; it fails to warn readers that: where the tools of lean are utilised merely as ad hoc interventions to deal with specific issues they are effective only to a limited extent and can result in measures and metrics that are internally focused, rather than customer focused ${ }^{55}$. As Seth and Gupta ${ }^{56}$ put it: "[t]here is a difference between doing lean and being lean". Indeed, of those organisations that currently utilise lean principles/techniques, only a very small minority manage to realise the true potential and results of a lean culture ${ }^{57}$.

Accordingly, whilst the measures outlined above do have significant potential to improve the quality and efficiency of clinical teaching within the Subject Group, the greatest potential lies in measures that might support a much needed cultural shift towards a lean philosophy, whereby all academic members of staff share a common vision to see the lives of students transformed with minimal waste, and the maximum flow of valuable pedagogical experiences.

\footnotetext{
${ }^{55}$ Radnor, Z. J., Bateman, N., Esain, A., Kumar, M., Williams, S. J., \& Upton, D. M. Public Service Operations Management: A research handbook. (2016). New York: Routledge., pp. 69

${ }^{56}$ Seth, D., \& Gupta, V. 'Application of value stream mapping for lean operations and cycle time reduction: an Indian case study'. (2005). Production, Planning \& Control, 16(1), 44-59., pp.57

${ }^{57}$ Hogg, D. P. E. 'Lean in a Changed World'. (2011). Manufacturing Engineering, 147(3), 102-113., pp. 104
} 


\section{Implications}

The benefits of clinical legal education ('CLE') are well documented ${ }^{58}$, as are the merits of integrating such activity into the curriculum ${ }^{59}$; Chemerinsky ${ }^{60}$ even went so far as to argue that it was the most useful preparation that an aspiring solicitor could undertake. Furthermore, the forthcoming regulatory changes to qualification requirements for solicitors in England and Wales may expand these benefits even further, since various forms of CLE offered by universities might potentially count towards the 'qualifying work experience' that will be needed ${ }^{61}$.

However, as this case study shows, there are potentially significant resourcing issues associated with this teaching methodology, and this position is endorsed by the literature. For example - as compared with traditional academic modules - the holistic and evolving nature of assessment in clinical modules has been shown to intensify workloads for the staff involved ${ }^{62}$.

\footnotetext{
${ }^{58}$ See Brayne, H., Duncan, N., \& Grimes, R. Clinical Legal Education: Active Learning in Your Law School. (1998). London: Blackstone Press.; Bloch, F. S. (Ed.) The Global Clinical Movement: Education Lawyers for Social Justice. (2011). Oxford: OUP.

${ }^{59}$ Combe, M. M. 'Selling intra-curricular clinical legal education'. (2014). The Law Teacher, 48(3), 281295.

${ }^{60}$ Chemerinsky, E. '"Why not clinical education?"'. (2009). Clinical Law Review, Vol. 16., pp. 35-41.

${ }^{61}$ Dunn R., Roper V., \& Kennedy, V. 'Clinical legal education as qualifying work experience for solicitors'. (2018). The Law Teacher, 52(4), 439-452.

${ }^{62}$ Bilgin, A. A., Rowe, A. D., \& Clark, L. 'Academic workload implications of assessing student learning in work-integrated learning'. (2017). Asia-Pacific Journal of Cooperative Education, 18(2), 167183.
} 
The development of work planning processes that operate equitably across a wide range of very diverse activities is a long running challenge faced by HE institutions ${ }^{63}$, but research suggests that this is most likely to be achieved where such workload allocation processes are developed in consultation with the academic staff involved ${ }^{64}$. The present case study has highlighted some of the pressure points for academic workloads in university law clinics and - using lean management methodologies has identified a proposed solution. To the extent that the proposed process delivers any efficiency improvement at all, it will represent an important step in supporting much needed sustainability of what is quickly becoming an essential component of any law programme.

\section{Limitations and opportunities for further research}

This paper summarised the initial stages of a long journey toward lean thinking within the Subject Group and as such is the first attempt in legal education. Since this research comprises only a single case study, its generalisability may be limited to law clinics/law schools with similar structures and/or challenges, and further thought and/or investigation may be needed in order to apply its findings within other law schools. As a follow-up study, the authors intend to monitor the results of

\footnotetext{
${ }^{63}$ see Burgess, T. F., Lewis, H. A., \& Mobbs, T. 'Academic workload planning revisited'. (2003). Higher Education, 46(2), 215-233.

${ }^{64}$ Kenny, J. D. J., \& Fluck, A. E. 'The effectiveness of academic workload models in an institution: a staff perspective'. (2014). Journal of Higher Education Policy and Management, 36(6), 585-602.
} 
the process revisions articulated in this paper, and compare the aforementioned performance measurements after full implementation of the proposed process model. In addition, the authors would welcome further empirical research which strengthens the evidence for the utility of lean thinking within the law clinic and within legal practice more generally. 